\title{
Save a Child: How to Identify and Report Child Abuse ${ }^{1}$
}

\author{
Andrew E. Toelle and Kate Fogarty ${ }^{2}$
}

Child abuse is a real problem and a concern for all persons working with children. In 2011, 3.4 million cases of child abuse were reported nationally; in $20 \%$ of these cases, children were confirmed to have been victims of some form of abuse in an estimated 681,000 unique cases (USDHHS, 2011). The rate of incidence for Native American and African-American children was above 20 incidents per thousand, almost twice that of their white counterparts; however, $43.9 \%$ of child abuse victims are white, whereas only $21.5 \%$ are African-American, $22.1 \%$ are Hispanic, and $1.1 \%$ are Native American or Alaska Native (USDHHS, 2011). Meanwhile, data from a University of Florida study on child welfare indicates that given identical family situations, abuse is more likely to be substantiated with regard to black children than with white children (Askew Institute, 2006).

In the 2008-2009 fiscal year, a reported 110,795 cases of abuse were verified in Florida (FDCF, 2011). Fortunately, this number declined to 51,555 in the 2010-2011 fiscal year. However, child abuse and re-abuse rates in Florida are on the rise (FDCF, 2010). The greatest tragedy of child abuse is summarized in this troubling statistic: an estimated 1,026 children died nationally as a result of child abuse in 2010, a number that has decreased by 504 over the past four years; as of 2010 in Florida, about 180 deaths were the result of abuse or neglect, a number much higher in comparison to those reported from other states (USDHHS, 2010).

People who work with children, parents, and the general public may at some point in their lives and careers have to report child abuse. It is important that you be able to recognize the symptoms of abuse and be able to contact the appropriate authorities. By reporting abuse, you may save a child's life or prevent serious injury.

This publication discusses child abuse laws and procedures for reporting abuse. It also contains information about different types of abuse and how to identify abused or neglected children. Characteristics listed here are general and intended as guidelines. A child or family may exhibit many warning signs of abuse, though no abuse has occurred or ever will occur.

Prior to April 2012, Florida law required only child care providers, physicians, teachers, law enforcement officers, and any other person having reason to believe a child under the age of 18 is being abused, to report abuse. Failure to report suspected abuse was regarded as a misdemeanor.

Since then, Governor Scott signed into law one of the nation's strictest abuse reporting bills (Business Wire, 2012). Florida House Bill 1355 on the "Protection of Vulnerable Persons," signed in April 2012, proposes a fine of up to $\$ 1$ million on any college or university, public or private, whose administration or law enforcement willfully and knowingly fails to report child abuse occurring on campus in facilities or at university-sponsored events and functions. The Act requires the Florida Child Abuse Hotline to take allegations of child abuse reports even if the suspected abuser is not a caregiver or parent, and it has provisions for

1. This document is FCS2119, one of a series of the Department of Family, Youth and Community Sciences, Florida Cooperative Extension Service, Institute of Food and Agricultural Sciences, University of Florida. Publication dates: January 2013, November 2008, July 2005, August 1999 , April 1997. Visit the EDIS website at http://edis.ifas.ufl.edu/.

2. Andrew E. Toelle, Extension agent III, Duval County, and Kate Fogarty, associate professor, Department of Family, Youth and Community Sciences; Florida Cooperative Extension Service, Institute of Food and Agricultural Sciences, University of Florida, Gainesville, FL 32611. 
relocation of child victims of sexual assault when there is reasonable concern for their safety.

Most importantly, everyone must report abuse. Reporting suspected child abuse is no longer limited to teachers, law enforcement, and health care professionals. Florida now has the only fully mandatory abuse reporting law in the nation.

There are many different ways to report abuse. You may call the Department of Children and Families (DCF) Central

Abuse Hotline at 1-800-96ABUSE (1-800-962-2873). The TDD number is 1-800-453-5145. DCF has developed an online process of reporting that is very useful in filing your report. It is located on the web at http://www.dcf.state.fl.us/ abuse/report/. More information about child protection in Florida is available from the DCF website at http://www.dcf. state.fl.us/abuse/. It is not the responsibility of the person reporting the suspected abuse to determine if abuse has occurred. An investigator will be assigned to determine this. Florida has an immunity law as well. This law protects you from lawsuits that could arise from reporting of the abuse so long as the incident is reported in "good faith."

Remember: Report child abuse to protect the child, not to punish the suspected abuser.

\section{Indicators of Physical Abuse}

Physical child abuse is the intentional harming of a child by an adult. This harm may include excessive shaking, bruising, beating (for example, with fists, belt, board, wire hanger, etc.), or burning (for example, scalding water, cigarette butts). Conservative estimates put rates of physical child abuse in Florida at 47,000 cases annually (Child Maltreatment, 2010).

A common myth classifies child abuse as a problem of the poor. However, child abusers may be from any socioeconomic class, race, educational background, or religion.

Physically abused children can be identified by various means.

\section{Physical Signs of Physical Abuse}

- Cuts, bruises, or broken bones in different stages of healing

- Burns

- Unrealistic explanations for how injuries occurred

\section{Behavioral Signs of Physical Abuse}

- Aggressive or disruptive behaviors
- Excessively passive, such as shrinking at the approach of adults

- Fear of going home or of certain people

\section{Indicators of Sexual Abuse}

Sexual abuse is sexual contact with a child by another person who may use force or threats, or exploits a position of authority. Like physical abuse, sexual abuse is not linked to any particular class, cultural group, or even age. For example, recent attention has been given to child-on-child sexual abuse, which most likely is the case of a victimized child re-enacting his/her abuse upon another child. ${ }^{\star}$ The sexual abuser is most often a parent, guardian, relative, family friend, or someone the child knows. Acts of sexual abuse perpetrated by strangers are usually single episodes with many different children, while familial sexual abuse is usually multiple occurrences to the same child over a period of months or years.

* Child-on-child sexual abuse still needs to be reported the same way as other forms of abuse. Make sure to note the age of the child perpetrator as a case involving a child 12-years-old or younger will be handled different than a child age 13 or older.

The common characteristics of a sexually abused child are discussed below.

\section{Physical Signs of Sexual Abuse}

- Trauma to the mouth, anus, or vagina (may include difficulty walking or sitting)

- Anal or vaginal bleeding

- The presence of semen or an enlarged vagina

- Painful urination

- Inability to control bowels

\section{Behavioral Signs of Sexual Abuse}

- Inappropriate sex play with peers or sexual knowledge unusual for age (may be revealed in drawings or stories)

- Inappropriate focus on genitals of self or others

- Reversion to more childlike behaviors (such as crying for no apparent reason)

- Withdrawal, depression, or change in personality 


\section{Indicators of Child Neglect}

Child neglect is a condition in which a child's basic needs for food, shelter, clothing, prompt medical attention, and emotional support are not met. Unlike physical and sexual abuse, child neglect is a result of what parents or guardians fail to do for their children, not what they do to their children. This is the most common form of child abuse, representing $78.5 \%$ of all child abuse cases (USDHHS, 2011).

Similar to physical and sexual abusers, persons who neglect their children may be from any socioeconomic class, race, sex, religion, or educational background. Common indicators of child neglect include the following.

\section{Physical Signs of Child Neglect}

- Child is inappropriately dressed for weather

- Extreme hunger indicated by a child

- Unkempt appearance of a child

- A child has not seen a physician in a timely manner for an illness

\section{Behavioral Signs of Child Neglect}

- Extreme misbehavior of a child

- A child gives excessive attention to others (for example, very "clingy" behavior)

\section{Reporting Child Abuse or Neglect}

Once you suspect abuse or neglect, you need to contact the proper authorities. Florida has the Florida Department of Children and Families. This organization is staffed by trained individuals who will take your call, and act upon the information you give them. Before you call, be sure you have the following information about the child:

- The child's name, age, address, and phone number

- The day you first noticed the abuse or neglect

- Any marks on the child and location of the marks

- Any other notable symptoms

- Any other important information

The fax transmittal form at http://www.dcf.state.fl.us/programs/abuse/docs/faxreport.pdf is an excellent source for reporters to write down the information needed for DCF investigators. Do not be concerned if you do not know all of the information on the form. List what you do know.

After a report is taken, a priority is given to it, either immediate or 24-hour. All investigations are to commence within 24 hours of receiving the report. An investigator will interview the child and other sources to determine if abuse has occurred. (Just because you find marks on a child does not mean he or she was abused.)

If abuse or neglect has occurred, the caseworker will attempt to find out who is abusing or neglecting the child and/or refer the case to law enforcement. If it is a parent or guardian, the caseworker will establish the level of risk to the child and determine if separation is appropriate. Separation is usually temporary and requires a court order. When the home situation is stabilized, the child and his or her parent(s) may be reunited. Only in extreme situations is the child removed permanently from a home. DCF attempts to keep the family together, but the safety of the child comes first.

\section{Summary}

Abuse and neglect may happen to any child at any time by anyone. Contact your local Children and Family Services office for more information, training, and special local programs that protect children and strengthen families. By recognizing some common symptoms of abuse and neglect, you can bring about early intervention to alleviate a child's suffering and provide treatment for an abusive person.

On a positive note, Florida is believed to have "one of the most innovative child abuse systems in the entire country" based on their creation (unique to Florida) of state-funded child protection teams (Askew Institute, 2006, p. 14), as well as recently adopting House Bill 1355 in Florida law. Child protection teams have a goal of investigating suspected cases of child abuse and neglect and making appropriate referrals to service providers. For example, a multidisciplinary child protection team (within the Children's Medical Services Center) at the University of Florida involves attorneys, pediatricians, psychologists, medical assistants, mental health counselors, social workers, and information systems specialists. This team serves 2 districts in the DCF and 16 North Central Florida counties. 


\section{Selected State and National Child} Abuse Prevention Organizations

\section{The Florida Central Abuse Hotline}

(Voice): 1-800-962-2873

(TDD): 1-800-453-5145

(Fax): 1-800-914-0004

Website for Reporting and Information: http://www.dcf. state.fl.us/abuse/report

\section{The National Exchange Club}

3050 Central Ave.

Toledo, $\mathrm{OH} 43606-1700$

Phone: 419-535-3232

Toll-free: 800-XCHANGE (924-2643)

E-mail: nechq@aol.com

http://www.nationalexchangeclub.com/

\section{Prevent Child Abuse America}

200 S. Michigan Avenue

17th Floor

Chicago, IL 60604-2404

Phone: $312-663-3520$

Fax: 312-939-8962

E-mail: mailbox@preventchildabuse.org

http://www.preventchildabuse.org/

Informational resource on reporting child abuse in Florida is available at: http://www.dcf.state.fl.us/abuse/publications/ mandatedreporters.pdf

\section{Parent's Anonymous ${ }^{\circledast}$ Inc.}

675 West Foothill Blvd., Suite 220

Claremont, CA 91711-3475

Phone: 909-621-6184

E-mail (for general information): Parentsanonymous@

parentsanonymous.org

http://www.parentsanonymous.org/

\section{Childhelp USA National Headquarters}

15757 N 78th St.

Scottsdale, AZ 85260

Phone: 800-422-4453

http://www.childhelpusa.org/

\section{Bibliography}

Business Wire (2012, April 27). Governor Scott Signs into Law Nation's Toughest Abuse Reporting Bill. Retrieved May 24, 2012 from http://www.businesswire.com/news/ home/20120427006023/en/Gov.-Scott-Signs-LawNation\%E2\%80\%99s-Toughest-Abuse.

Cicchetti, D. \& Toth, S. L. (2003). Past, present and future perspectives. In R. P. Weissberg, H. J. Walberg, M. U. O'Brien, \& C. B. Kuster (Eds.), Long-term trends in the well-being of children and youth. Washington, DC: CWLA Press.

Either, S. E., Couture, G., \& Lacharté, C. (2004). Risk factors associated with the chronicity of high potential for child abuse and neglect. Journal of Family Violence 19(1), 13-24.

Florida Department of Children and Families (2011). DCF QuickFacts. Retrieved May 24, 2012 from Florida Department of Children and Families website at http://www.dcf. state.fl.us/newsroom/docs/quickfacts.pdf.

Florida Department of Children and Families (2010). FFY 2009-2010 Annual Progress and Services Report. Retrieved May 24, 2012 from Florida Department of Children and Families website at http://www.dcf.state.fl.us/admin/ publications/docs/FFY09-10APSR.pdf.

Mandatory Reports of Child Abuse and Neglect, FL Code $\$ \$ 39.201-39.202$.

The Reubin O'D. Askew Institute (March, 2006). Child welfare issues in Florida and the nation. A University of Florida Report. Gainesville, Florida.

U.S. Dept. of Health \& Human Services (2011). Child Maltreatment, 2011. Retrieved December 14, 2012 from U.S. Department of Health and Human Services, Administration for Children and Families website at http://www.acf. hhs.gov/sites/default/files/cb/cm11.pdf. 